\title{
High-dose testosterone supplementation disturbs liver pro- oxidant/antioxidant balance and function in adolescent male Wistar rats undergoing moderate-intensity endurance training
}

\author{
Ewa Sadowska-Krępa ${ }^{1}$, Barbara Kłapcińska ${ }^{1}$, Anna Nowara ${ }^{1}$, Sławomir Jagsz ${ }^{1}$, Izabela Szołtysek-Bołdys ${ }^{2}$, \\ Małgorzata Chalimoniuk ${ }^{3}$, Józef Langfort ${ }^{1}$, Stanisław J Chrapusta ${ }^{\text {Corresp. } 4}$ \\ 1 Institute of Sport Sciences, The Jerzy Kukuczka Academy of Physical Education, Katowice, Silesian Voivodeship, Poland \\ 2 Department of General and Inorganic Chemistry, School of Pharmacy with the Division of Laboratory Medicine in Sosnowiec, Medical University of \\ Silesia, Sosnowiec, Silesian Voivodeship, Poland \\ 3 Department of Physical Education and Health in Biała Podlaska, Józef Piłsudski University of Physical Education in Warsaw, Biała Podlaska, Lublin \\ Voivodeship, Poland \\ 4 Department of Experimental Pharmacology, Mossakowski Medical Research Centre Polish Academy of Sciences, Warsaw, Mazowieckie Voivodeship, \\ Poland
}

Corresponding Author: Stanisław J Chrapusta

Email address: sjchrapusta@imdik.pan.pl

In some countries, anabolic-androgenic steroid abuse is rampant among adolescent boys and young men, including some of those seeking physical fitness and/or pleasing appearance through various exercise types. This tactic carries the risk of severe harmful health effects, including liver injury. Most anabolic-androgenic steroid stacking protocols employed are based on the use of the 'prototypic' anabolic-androgenic steroid testosterone and/or its esters. There is a vast body of data on the effects of anabolicandrogenic steroids' abuse combined with physical exercise training on the liver antioxidant barrier in adult subjects, whereas those concerning adolescents are scant. This study aimed at assessing, in adolescent male Wistar rats undergoing a 6-week moderateintensity endurance training (treadmill running), the influence of concurrent weekly supplementation with intramuscular testosterone enanthate (TE, 8 or $80 \mathrm{mg} / \mathrm{kg}$ body weight/week) on selected indices of liver status and oxidative stress. The rats were sacrificed, and their livers and blood samples were harvested two days after the last training session. High-dose TE treatment significantly reduced body and liver weight gains. Neither low-dose nor high-dose TE treatment affected liver $\alpha$-tocopherol or $\gamma$-tocopherol content, whereas low-dose TE treatment significantly lowered hepatic reduced glutathione content. TE treatment significantly elevated liver thiobarbituric acid-reactive substances content and blood activities of alkaline phosphatase and $\gamma$-glutamyltransferase, but not of aspartate aminotransferase or alanine aminotransferase. Liver catalase activity was lowered by $>50 \%$ in both TE-treated groups, while superoxide dismutase activity was significantly but slightly affected $(-15 \%)$ only by the high-dose TE treatment. Glutathione 
peroxidase and glutathione reductase activities were not significantly altered. TE treatment significantly increased liver thiobarbituric acid-reactive substances' content and lowered blood HDL-cholesterol, but did not significantly affect LDL-cholesterol or triglycerides level. In conclusion, high-dose TE treatment significantly disturbed liver antioxidant barrier and prooxidative-antioxidative balance and hence counteracted favorable effects of concurrent moderate-intensity endurance training in adolescent male rats. 
1 High-dose testosterone supplementation disturbs liver pro-oxidant/antioxidant balance

2

3

4

5

6

7

8

9

10

21

22 and function in adolescent male Wistar rats undergoing moderate-intensity endurance training

Ewa Sadowska-Krępa ${ }^{1}$, Barbara Kłapcińska ${ }^{1}$, Anna Nowara1 ${ }^{1}$, Sławomir Jagsz ${ }^{1}$, Izabela Szołtysek-Bołdys ${ }^{2}$, Małgorzata Chalimoniuk ${ }^{3}$, Józef Langfort ${ }^{1}$, Stanisław J. Chrapusta ${ }^{*}$ *

${ }^{1}$ Institute of Sport Sciences, The Jerzy Kukuczka Academy of Physical Education, Katowice, Silesian Voivodeship, Poland

2 Department of General and Inorganic Chemistry, School of Pharmacy with the Division of Laboratory Medicine in Sosnowiec, Medical University of Silesia, Sosnowiec, Silesian Voivodeship, Poland

${ }^{3}$ Department of Physical Education and Health in Biała Podlaska, Józef Piłsudski University of Physical Education in Warsaw, Biała Podlaska, Lublin Voivodeship, Poland

${ }^{4}$ Department of Experimental Pharmacology, Mossakowski Medical Research Centre Polish Academy of Sciences, Warsaw, Mazovian Voivodeship, Poland

* Corresponding Author:

Stanisław J. Chrapusta, PhD

Department of Experimental Pharmacology

Mossakowski Medical Research Centre

5 Pawińskiego St., 02-106 Warsaw, Poland

Email: sjchrapusta@imdik.pan.pl 


\section{Abstract}

31 In some countries, anabolic-androgenic steroid abuse is rampant among adolescent boys and 32 young men, including some of those seeking physical fitness and/or pleasing appearance through various exercise types. This tactic carries the risk of severe harmful health effects, including liver injury. Most anabolic-androgenic steroid stacking protocols employed are based on the use of the 'prototypic' anabolic-androgenic steroid testosterone and/or its esters. There is a vast body of data on the effects of anabolic-androgenic steroids' abuse combined with physical exercise training on the liver antioxidant barrier in adult subjects, whereas those concerning adolescents are scant. This study aimed to assess, in adolescent male Wistar rats undergoing a 6-week moderate-intensity endurance training (treadmill running), the influence of concurrent weekly supplementation with intramuscular testosterone enanthate (TE, 8 or $80 \mathrm{mg} / \mathrm{kg}$ body weight/week) on selected indices of liver status and oxidative stress. The rats were sacrificed, and their livers and blood samples were harvested two days after the last training session. Highdose TE treatment significantly reduced body and liver weight gains. Neither low-dose nor highdose TE treatment affected liver $\alpha$-tocopherol or $\gamma$-tocopherol content, whereas low-dose TE treatment significantly lowered hepatic reduced glutathione content. TE treatment significantly elevated liver thiobarbituric acid-reactive substances content and blood activities of alkaline phosphatase and $\gamma$-glutamyltransferase, but not of aspartate aminotransferase or alanine aminotransferase. Liver catalase activity was lowered by $>50 \%$ in both TE-treated groups, while superoxide dismutase activity was significantly but slightly affected (-15\%) only by the highdose TE treatment. Glutathione peroxidase and glutathione reductase activities were not significantly altered. TE treatment significantly increased liver thiobarbituric acid-reactive substances' content and lowered blood HDL-cholesterol, but did not significantly affect LDLcholesterol or triglycerides level. In conclusion, high-dose TE treatment significantly disturbed liver antioxidant barrier and prooxidative-antioxidative balance and hence counteracted favorable effects of concurrent moderate-intensity endurance training in adolescent male rats. 


\section{Introduction}

59 Endurance training (EndTr) plays a key role in various endurance sports, e.g., cross-country

60 skiing, long-distance running, and cycling. However, it can also be a vital addition to both

61 bodybuilding (M. Barroso. 8 tips for balancing bodybuilding and endurance training; for the

62 URL, see $<$ WWW-references.docx $>$ in Supplemental Files) and strength training, particularly in

63 team sports (Coffey \& Hawley, 2017). It also gets growing attention from the general public as a

64 health-promoting factor when used in moderation (Fikenzer et al., 2018; Ruegsegger \& Booth,

65 2018); the positive effects of the training also concern liver health (Shephard \& Johnson, 2015).

66 Some adolescents and young adults, mostly males (Kanayama \& Pope, 2018; Johnston et al.,

67 2019), combine endurance-oriented physical training with the use of testosterone and/or its

68 synthetic derivatives termed anabolic-androgenic steroids (AAS). The main goal of this tactic is

69 a faster reduction of body fat and boosting muscularity with the idea of improving physical

70 performance and appearance (Hartgens \& Kuipers, 2004; Kanayama \& Pope, 2018), and hence

71 self-esteem. A positive correlation of the bodily effects with dosage inspires AAS abuse at high

72 doses. Some endurance athletes reported the effectiveness of AAS for accelerating the recovery

73 after intense physical exercises (Hartgens \& Kuipers, 2004). AAS were also reported to improve

74 running endurance in male rats (Van Zyl, Noakes \& Lambert, 1995; Georgieva \& Boyadjiev,

75 2004), but no positive AAS effect on endurance or blood serum markers recovery was seen in

76 other rat studies (Delgado, Saborido \& Megias, 2010) or healthy men (Baume et al., 2006).

77 Xenobiotics and excess endobiotics are mostly processed and removed by the liver; this

78 situation renders this organ the critical site of steroid toxicity (Russmann, Kullak-Ublick \&

79 Grattagliano, 2009; Vinken et al., 2013). The abuse of AAS and their 'prototypic' testosterone is

80 associated with a variety of severe adverse health effects (Hartgens \& Kuipers, 2004; van

81 Amsterdam, Opperhuizen \& Hartgens, 2010; Vanberg \& Atar, 2010), including a number of

82 those directly linked to liver injury (Russmann, Kullak-Ublick \& Grattagliano, 2009; Bond,

83 Llewellyn \& Van Mol, 2016; Solimini et al., 2017). A growing body of data links this damage to

84 a variety of genomic and nongenomic actions of these drugs, including enhanced generation of

85 reactive oxygen species and lipid peroxidation, and the related activation of cellular stress-

86 signaling pathways (Russmann, Kullak-Ublick \& Grattagliano, 2009; Cerretani et al., 2013;

87 Bond, Llewellyn \& Van Mol, 2016). Disruption of redox homeostasis is a well-established event

88 in both drug hepatotoxicity and various liver diseases (Cichoż-Lach \& Michalak, 2014; Li et al., 
89

90

91

92

93

94

95

96

97

98

99

100

101

102

103

104

105

106

107

108

109

110

111

112

113

114

115

116

117 $11817 \alpha$-alkylation) of the sterane core in most AAS (Hartgens \& Kuipers, 2004; Russmann, Kullak119 Ublick \& Grattagliano, 2009; Büttner \& Thieme, 2010).

2015; Arauz, Ramos-Tovar \& Muriel, 2016). The primary sources of reactive oxygen species, the noxious mediators of oxidative stress, are cytochrome P450 enzymes of the endoplasmic reticulum and mitochondria (Guengerich, 2008; Jones, 2008) and several enzymes present in peroxisomes that abound in the liver (Cerretani et al., 2013; Cichoż-Lach \& Michalak, 2014).

Hepatocytes carry several systems capable of preventing or limiting the adverse effects of enhanced oxidative stress (Jones, 2008; Frankenfeld et al., 2014; Sies, 2015). These systems include various antioxidant enzymes, e.g., glutathione peroxidase (GPx), glutathione reductase (GR), superoxide dismutase (SOD) and catalase (CAT), and low molecular weight antioxidants, e.g., tocopherols and reduced glutathione (GSH) that act mostly in lipophilic and hydrophilic milieus, respectively. Data on the effects of AAS abuse combined with physical exercise training on the liver antioxidant barrier in adolescent subjects are scarce (Molano et al., 1999; Pey et al., 2003). Adolescence is a period when some people, mainly boys, become familiar with AAS as drugs of abuse. It is also a period of essential changes in androgen catabolism in men (Horst, Bartsch \& Dirksen-Thiedens, 1977; Belgorosky \& Rivarola, 1987a; Belgorosky \& Rivarola, 1987b; Stárka, Pospísilová \& Hill, 2009), which condition may significantly modify the outcome of androgen action (Mantovani \& Fucic, 2014).

Our earlier study on the effects of long-term testosterone treatment on the liver antioxidant barrier and some blood markers of liver injury in sedentary adolescent male rats showed some signs of enhanced liver oxidative stress and toxicity but no potential lasting harm (SadowskaKrępa et al., 2017). Here, we tested the possible harmful effects of this treatment in a situation aimed to model androgen abuse to aid physical exercise training. The studied constituents of hepatic antioxidant defense systems included selected antioxidant enzymes (SOD, CAT, GPx, and GR) and nonenzymatic low molecular weight antioxidants ( $\alpha$ - and $\gamma$-tocopherols and GSH); liver thiobarbituric acid-reactive substances (TBARS) content was assayed as an index of oxidative stress. Our choice of testosterone enanthate (TE) was mainly based on the fact that testosterone was for many years among the most frequently abused doping drugs (Handelsman, 2006), and testosterone formulations (chiefly esters) are a cornerstone of most oral and injectable AAS stacking regimens (for the respective URLs see $<$ WWW-references.docx $>$ in Supplemental

17 Files). However, we also intended to avoid hepatotoxicity related to chemical alteration (mostly 


\section{Materials \& Methods}

121 Animals

122 Five-week-old healthy specific pathogen-free male outbred Wistar rats of 91-120 g initial body

123 weight (BW) from the Cmd:(WI)WU stock maintained at the Mossakowski Medical Research

124 Centre, Warsaw, Poland, were used for the study. They were housed 4-5 per opaque plastic cage

125 (60 × $38 \mathrm{~cm}$ floor size $)$ with dust-free deciduous wood chip bedding, in a controlled environment 126 room $\left(22-24{ }^{\circ} \mathrm{C}, 45-65 \%\right.$ relative humidity, $15-20$ air changes per hour), under 12 hours/12 hours

127 light-dark cycle (lights on at 7 a.m.). Throughout the study (excepting an 8-hour fast just before

128 the sacrifice, see below), the rats were allowed autoclaved laboratory rat maintenance chow 129 (ssniff Spezialdiäten GmbH, Soest, Germany) and autoclaved purified tap water ad libitum. The

130 cage environment was enriched with deciduous wood shavings as a material for gnawing and 131 nesting; after each bedding change, a few fresh chow pellets were also left on the cage floor for 132 playing and gnawing. The water bottles were replaced twice a week, and the bedding and 133 enrichment material were changed weekly or more frequently if needed.

134 Drugs

135 Stock TE solution (Testosteronum prolongatum, Jelfa, Jelenia Góra, Poland; active substance: 136 testosterone enanthate, $100 \mathrm{mg} / \mathrm{ml}$ ) was diluted with sesame oil (Sigma-Aldrich, St. Louis, MO, 137 USA) as necessary to provide the same injection volume of $1 \mathrm{ml} / \mathrm{kg}_{\mathrm{BW}}$ irrespective of weekly TE 138 dose employed. The diluted solution was injected intramuscularly each Monday for six weeks, 139 alternatively into the left and right hind leg. TE-untreated rats received $1 \mathrm{ml} / \mathrm{kg}_{\mathrm{BW}}$ of the oil by 140 an identical schedule.

141 Experimental design

142 All rats meant for EndTr were first run-tested (at 18-20 m/min, $0^{\circ}$ slope, $3 \times 5$ min daily, with

143 15-min breaks) for three consecutive days on a BTP-10 motorized rodent treadmill (Porfex,

144 Białystok, Poland) to acquaint them with this setting and identify and exclude rats reluctant to 145 exercise. A low-intensity electrical shock $(0.5 \mathrm{~mA}, 170 \mathrm{~V} \mathrm{AC})$ was used during the habituation to 146 motivate the rats to run. Two rats that were found unwilling to run during the habituation period 147 did not enter the experiment. The remaining rats were randomly divided between three groups:

148 1) TE-untreated EndTr rats (EndTr, $\mathrm{N}=11)$, 2) EndTr rats given $8 \mathrm{mg} / \mathrm{kg}_{\mathrm{BW}} /$ week of TE 149 (EndTr+TE8, $\mathrm{N}=11)$ and 3) EndTr rats given $80 \mathrm{mg} / \mathrm{kg}_{\mathrm{BW}} / \mathrm{week}$ of TE (EndTr+TE80, $\left.\mathrm{N}=12\right)$. 
150 An additional group of naïve sedentary (untrained, UTr, $\mathrm{N}=11$ ) male Wistar rats from the same 151 stock and kept under the same conditions, 11-12-week old at the moment of sacrifice, was used 152 to estimate reference ranges of blood serum lipids. All the rats belonging in the EndTr, 153 EndTr+TE8, and EndTr +80 group were trained to run (at $0^{\circ}$ slope) on the treadmill five days a 154 week (Monday through Friday) for six weeks starting two days after the last habituation session. 155 Treadmill speed was gradually elevated from $16 \mathrm{~m} / \mathrm{min}$ for the first week to $28 \mathrm{~m} / \mathrm{min}$ for the 156 fourth week and then was kept steady. The EndTr session duration for weeks 1-4 began at 40 157 min/day each week and was extended by 5 min daily; for the last two weeks, the rats ran for 60 min daily. This moderate-intensity EndTr (at about $60 \% \mathrm{VO}_{2} \mathrm{max}$ ) was shown by various

159 160

161

162 163

164

165 166

167 168 169

170

171

172

173

174

175

176

177

178

179

180 measures to improve endurance in rats (Langfort, Budohoski \& Newsholme, 1988; Langfort et al., 1996; Dobrzyn et al., 2013). One rat of the EndTr group and two rats of the EndTr+TE8 group developed an aversion to run and showed noticeable weight loss (by $\geq 10 \%$ over a single week) at some time point of the training course. These rats were euthanized by decapitation while deeply anesthetized with an intraperitoneal injection of a solution of pentobarbital sodium and pentobarbital $(50 \mathrm{mg} / \mathrm{ml}$ and $10 \mathrm{mg} / \mathrm{ml}$, respectively; Vetbutal, Biowet Puławy, Poland) at a dose of $80 \mathrm{mg} / \mathrm{kg}_{\mathrm{BW}}$. Two days after the last EndTr session, all the surviving endurance-trained rats and the UTr rats were fasted for 8 hours, anesthetized with an intraperitoneal injection of the pentobarbital sodium and pentobarbital mixture as above, and decapitated. Trunk blood samples were collected, let to clot at room temperature, and centrifuged to yield serum for biochemical assays. Livers were perfused in situ with $10 \mathrm{mM}$ glucose-supplemented cold Krebs-Henseleit buffer $\mathrm{pH} 7.4$, then quickly removed, weighed, and cut into several pieces that were instantly frozen in liquid nitrogen and stored at $-80^{\circ} \mathrm{C}$ until analyzed. The study protocol complied with the Directive 2010/63/EU of the European Parliament and of the Council of 22 September 2010 on the protection of animals used for scientific purposes, was in line with the respective Polish law then in force, and was accepted by the IV Local Ethics Committee for Animal Experimentation in Warsaw, Poland (Permit No. 38/2011).

\section{Assay methods}

All biochemical determinations in blood serum and liver samples, except for serum lipids that were not determined before, were performed as described earlier (Sadowska-Krępa et al., 2017). Specifically: The total serum testosterone (TT) level was assessed with a DSL-4100 Testosterone RIA Kit (Diagnostic Systems Laboratories, Webster, TX, USA). Serum activities of aspartate 
181 aminotransferase (AST; EC:2.6.1.1), alanine aminotransferase (ALT; EC:2.6.1.2), alkaline 182 phosphatase (ALP; EC:3.1.3.1), and $\gamma$-glutamyltransferase (GGT; EC:2.3.4.2) were determined 183 on a model Cobas Integra 400/800 analyzer (Roche, Switzerland). For antioxidant status testing, 184 liver samples were homogenized in ice-cold buffers prepared according to the respective 185 diagnostic kit instructions, using a model Ultra-Turrax T8 homogenizer (IKA Labortechnik, 186 Staufen, Germany). Protein content in homogenate supernatants was determined with the BCA-1 187 Protein Assay Kit (Sigma-Aldrich, UK). CAT (EC:1.11.1.6) activity was measured as described 188 by Aebi (1984), while GSH content and GPx (EC:1.11.1.9) and GR (EC:1.6.4.2) activities were 189 assessed with Bioxytech kits GSH-400, GPx-340, and GR-340, respectively (OXIS International, 190 Portland, OR, USA). SOD (EC:1.15.1.1) activity was assessed with a Superoxide Dismutase

191

192

193

194 195

196

197

198

199

200

201

202

203

204

205

206

207

208

209

210

211 Assay Kit (Cayman Chemical, Ann Arbor, MI, USA). Liver contents of $\alpha$ - and $\gamma$-tocopherol were quantified by HPLC (Sobczak, Skop \& Kula, 1999), while that of thiobarbituric acidreactive substances (TBARS) was assessed as described by Ohkawa, Ohishi \& Yagi (1979) and expressed in malondialdehyde (MDA) units. Serum total cholesterol (Tot-Ch), HDL-cholesterol (HDL-Ch), and triglyceride (TG) levels were determined using commercial kits (CH-200, CH20, and TR-210, respectively) from Randox Laboratories (Crumlin, UK), while LDL-cholesterol (LDL-Ch) was assessed with a model Synchron CX9 Pro analyzer (Beckman-Coulter).

\section{Statistics}

Data are presented as the mean \pm SD if applicable. Body weight data were first analyzed by a two-way analysis of variance (ANOVA) with TE dose $\left(0,8\right.$, or $\left.80 \mathrm{mg} / \mathrm{kg}_{\mathrm{BW}}\right)$ as the main factor and repeated measure on time, followed by the Tukey test for unequal sample sizes. Blood serum lipid titers were compared by a one-way ANOVA followed by the Dunnett test. The occurrence of abnormal values of blood serum enzyme activities and lipid profile indices was compared by the one-tailed $z$-test for two proportions. All other data were analyzed by a one-way ANOVA with weekly TE dose as the main factor, followed by the Tukey test when appropriate.

Comparisons with data from our previous study (Sadowska-Krępa et al., 2017) were made using Student's $t$-test for independent variables, as indicated in the text. Associations between variables were assessed using the Spearman rank correlation test. In all cases, $\mathrm{p} \leq 0.05$ was considered significant. All the statistical analyses were run using the Statistica v. 12.5 software package (StatSoft, Tulsa, OK, USA). 


\section{Results}

213 Serum total testosterone level and body and liver weights

214 At the end of the study, the mean serum TT level in low-dose TE-treated (EndTr+TE8) rats

215 exceeded only marginally and nonsignificantly that in the TE-untreated rats, while that in their

216 high TE dose-treated counterparts (EndTr+TE80) was 10-fold higher. There was no difference in

217 BW gain between the rats given no or low-dose TE treatment, whereas both these groups showed 218 considerably higher BW gain than the EndTr+TE80 group. Mean liver weight and LW/BW ratio

219 in the EndTr+TE8 rats were significantly higher, while the mean LW but not mean LW/BW ratio 220 was significantly lower in the EndTr+TE80 rats than in the TE-untreated rats. The final BW and 221 the LW/BW ratio were significantly lower in the high-dose- than in the low-dose TE-treated rats 222 (Table 1). Across all three EndTr groups combined, the final BW, LV, and LV/BW ratio 223 correlated negatively with the weekly TE dose: $R_{S}=-0.65, p<0.001, R_{S}=-0.47, p<0.01$, and $R_{S}$ $224=-0.37, \mathrm{p}<0.05$, respectively; $\mathrm{N}=31$ for all.

225 Tissue antioxidant enzymatic and nonenzymatic indices of liver status

226 TE treatment resulted in a slight drop in mean SOD activity and a marked lowering of mean 227 CAT activity (Table 2). These activities also showed a significant negative correlation with the 228 weekly TE dose across all three EndTr groups combined $\left(R_{S}=-0.61\right.$ and $R_{S}=-0.78$, 229 respectively; $\mathrm{p}<0.001, \mathrm{~N}=31$ for both). In contrast, there was no sizable TE treatment-related 230 difference in mean GPx and GR activities between these groups and no sizable tendency for a 231 correlation with weekly TE dose across the EndTr study cohort (Table 2).

232 Both TE-treated groups showed somewhat lower liver GSH content than that in the TE233 untreated group, which difference reached significance for the low-dose TE treatment. No 234 tangible difference was found between the respective $\alpha$ - or $\gamma$-tocopherol levels. As compared 235 with hepatic TBARS content in the TE-untreated rats, that in the low-dose TE-treated rats was 236 but nonsignificantly higher $(+15 \%)$, while that in the other TE-treated group was significantly 237 and much ( $+48 \%$ ) higher (Table 2 ). Across all three EndTr groups combined, the TBARS 238 content positively correlated with the TE dose received $\left(\mathrm{R}_{\mathrm{S}}=0.51, \mathrm{p}<0.01, \mathrm{~N}=31\right)$.

239 Blood serum enzymatic indices of liver status

240 There was no significant difference in serum AST or ALT activity between the various EndTr 241 groups. Across all three EndTr groups combined, these activities did not or but poorly correlated 
242 with the weekly TE dose $\left(\mathrm{R}_{\mathrm{S}}=0.20, \mathrm{p}=0.27\right.$, and $\mathrm{R}_{\mathrm{S}}=0.36, \mathrm{p}=0.046$, respectively, $\mathrm{N}=31$ for 243 both). The rats given high-dose TE treatment showed significantly higher serum ALP and GGT 244 activities than their TE-untreated counterparts (Table 3 ). These activities correlated well with the 245 weekly TE dose across the three EndTr groups $\left(\mathrm{R}_{\mathrm{S}}=0.61, \mathrm{p}<0.001\right.$, and $\mathrm{R}_{\mathrm{S}}=0.69, \mathrm{p}<0.001$, 246 respectively, $\mathrm{N}=31$ for both). There was no correlation between any two of these indices within 247 this cohort $\left(\mathrm{R}_{\mathrm{S}} \leq 0.30, \mathrm{p} \geq 0.10, \mathrm{~N}=31\right)$.

248 The occurrence of above-normal AST activity was high in the TE-untreated EndTr rats and 249 even higher in their TE-treated counterparts. The occurrence of excessive activities of ALT and 250 GGT but not ALP tended to increase in the TE-untreated EndTr rats and was significantly 251 elevated in the TE-treated rats TE (Table 4). However, even the maximum activities exceeded 252 the upper limit of the respective reference range but moderately: AST - by $48 \%$, ALT - by $37 \%$, 253 ALP - by $6 \%$, and GGT - by $65 \%$.

254 Blood serum lipid profile

255 Across the entire cohort of endurance-trained rats, weekly TE dose showed significant negative 256 correlation with serum HDL-Ch level and Tot-Ch/HDL-Ch ratio $\left(\mathrm{R}_{\mathrm{S}}=-0.77, \mathrm{p}<0.001, \mathrm{~N}=31\right.$, 257 and $\mathrm{R}_{\mathrm{S}}=-0.51, \mathrm{p}<0.01$, respectively), and a tendency for weak correlation with TG but not 258 LDL-Ch level $\left(\mathrm{R}_{\mathrm{S}}=-0.31, \mathrm{p}=0.09\right.$, and $\mathrm{R}_{\mathrm{S}}=0.15, \mathrm{p}=0.41$, respectively, $\mathrm{N}=31$ for both). 259 Mean values of all tested lipid indices except HDL-Ch tended to be lower in the TE-untreated 260 EndTr rats than in their UTr counterparts, but the difference reached significance only for TG 261 level and neared significance for the TG/HDL ratio (Table 5). Both TE-treated EndTr groups 262 compared to their TE-untreated counterpart showed slightly and nonsignificantly lower mean 263 Tot-Ch but not mean LDL-Ch level, and significantly lower mean HDL-Ch level. Mean 264 Tot-Ch/HDL-Ch and LDL-Ch/HDL ratios were significantly higher in the EndTr+TE80 rats than 265 those in their TE-untreated counterparts and showed a similar tendency in the EndTr+TE8 rats. 266 The latter showed a nonsignificantly higher mean TG level than their TE-untreated counterparts, 267 while there was a tendency for a reverse difference between them and the EndTr+TE80 rats. Due 268 to no significant difference in mean HDL-Ch level between the TE-treated groups, the mean 269 TG/HDL-Ch ratio was significantly higher $(+63 \%)$ in the low-dose TE-treated, but not in the 270 EndTr+TE80 rats $(+20 \%)$ than in their TE-untreated counterparts (Table 5).

271 For lack of established reference ranges for blood lipids in Wistar rats, we estimated these 272 ranges as the mean \pm 2 S.D. of the levels found in the previously mentioned additional group of 
273 matched TE-untreated UTr rats. Except for an abnormally low TG level and TG/HDL-Ch ratio in

274 a single rat, no out-of-range value was found in the TE-untreated EndTr group. In contrast, the

275 TE-treated EndTr rat groups, and mainly that given the higher TE dose, showed an increased

276 occurrence of below-normal TG, Tot-Ch, and especially HDL-Ch levels, occasionally associated

277 with abnormally high LDL-Ch/HDL-Ch ratio (Table 6).

278

\section{Discussion}

280 The main finding of this work is that testosterone supplementation enhanced hepatic stress and 281 adversely altered liver pro-oxidant/antioxidant balance in EndTr adolescent male rats. These 282 effects were evidenced by the increased occurrence of elevated blood GGT, AST and ALT 283 activities, worsened blood lipid profile, reduced liver SOD and CAT activities and GSH content, 284 and elevated liver TBARS content. The higher TE dose significantly lowered BW gain and LW 285 as compared to those in TE-untreated EndTr rats, but caused no substantial shift in the LW/BW 286 ratio $(-5 \%, \mathrm{p}=0.66)$ and thus no apparent hepatotoxicity in EndTr rats. Earlier, we found a 287 significantly reduced LW/BW ratio in high-dose TE-treated adolescent UTr rats (Sadowska288 Krępa et al., 2017), which may have been due to the start of TE treatment at a younger age.

The training was performed at an intensity that allows maximal fat oxidation (Purdom et al., 290 2018), and the mean BW gains were less in all three EndTr groups than in the respective UTr 291 groups (see Sadowska-Krępa et al., 2017). Notably, mean BW gain was identical for the TE292 untreated and low-dose TE-treated groups in both the endurance-trained and UTr rat cohorts, 293 indicating no interference of this treatment with food intake and somatic growth. The lowered 294 BW gain in the EndTr+TE80 rats may also have resulted from reduced appetite and food intake. 295 Such effects causing inadequate compensation of energy expenditure were commonly found in 296 treadmill-trained male rats (Harpur, 1980; Molano et al., 1999; Foletto et al., 2015). However, 297 reduced food intake was seen as well in long-term stanozolol-treated sedentary male rats (Yu298 Yahiro et al., 1989). Another cause of reduced weight gain could be androgen-induced loss of 299 adipose tissue (mostly visceral) and liver fat through various mechanisms (Yu-Yahiro et al., 300 1989; De Pergola, 2000; Hoyos et al., 2012).

301 Elevated serum AST, ALT, ALP, and GGT are well-known markers of AAS hepatotoxicity 302 (Urhausen, Torsten \& Wilfried, 2003; Ozer et al., 2008; Singh, Bhat \& Sharma, 2011). However, 303 serum ALT and AST may also come from injured skeletal muscles (Ozer et al., 2008). Exercise 
304 training alone can elevate serum ALT and AST, but not GGT, in both men (Pettersson et al., 305 2008; Romagnoli et al., 2014) and male rats (Pey et al., 2003; Chang et al., 2013). We found no 306 significant difference between our TE-untreated EndTr rats and matching UTr rats in any of the 307 four markers but AST activity that was higher in the former ( $\mathrm{p}=0.024$, Student's $t$-test); for the 308 UTr rats' data, see Sadowska-Krępa et al. (2017). In the present study, raised serum AST, ALT, 309 and GGT but not ALP activities were found in a sizable subset of the EndTr+TE8 rats and most of the EndTr+TE80 rats. However, the mean AST and ALT activities in the latter were only higher by $1 / 3$ than those in the TE-untreated UTr rats (Sadowska-Krępa et al., 2017). Even smaller and nonsignificant were the relative increases in the mean AST (+6\%) and ALT activity $(+23 \%)$ in the EndTr+TE80 rats as compared to those in their TE-untreated counterparts, while the respective increase in the mean GGT activity was fairly robust $(+57 \%)$. Our data on the effects of the lower TE dose are in line with those reported by others. Namely, no sizable increase in serum AST, ALT, ALP, or GGT was found in adolescent male rats given 12 weeks of moderate-intensity EndTr and five intragastric doses weekly of $2 \mathrm{mg} / \mathrm{kg}_{\mathrm{BW}}$ of fluoxymesterone, methylandrostanolone, or stanozolol during the last eight weeks (Molano et al., 1999; Pey et al., 2003). Notably, these AAS are much more hepatotoxic than testosterone (Hartgens \& Kuipers, 2004; Russmann, Kullak-Ublick \& Grattagliano, 2009; Büttner \& Thieme, 2010).

We have earlier found significant increases in the mean serum level of AST, ALT, and ALP, but not GGT, in 5-week-old UTr rats given 6-week high-dose TE-treatment (Sadowska-Krępa et al., 2017). In the present study, $60 \%$ of the TE-untreated EndTr rats showed elevated serum AST levels indicating an exercise-related leakage of the enzyme from skeletal muscles. Unexpectedly, there was no significant TE-treatment-related increase in mean AST and ALT levels, while the high-dose TE treatment-related increase in mean ALP level was nearly identical to that in the UTr rats. However, contrary to the latter, the EndTr+TE80 rats showed a much higher mean GGT level than their TE-untreated counterparts. Serum ALT and ALP levels correlated positively with TE dosage in both the EndTr (see the Results section) and the UTr study cohort $\left(\mathrm{R}_{\mathrm{S}}=0.70, \mathrm{p}<10^{-3}\right.$, and $\mathrm{R}_{\mathrm{S}}=0.50, \mathrm{p}<10^{-2}$, respectively, $\mathrm{N}=37$ for both, see Supplemental Files, UTr_cohort_ser_enz_vs_TE_dose.xlsx). In contrast, weekly TE dose positively correlated with GGT but not AST level in the EndTr rats (this study), while the reverse was right in the UTr rats $\left(\mathrm{R}_{\mathrm{S}}=0.06, \mathrm{p}=0.72, \mathrm{~N}=34\right.$, and $\mathrm{R}_{\mathrm{S}}=0.74, \mathrm{p}<10^{-3}, \mathrm{~N}=37$, respectively, see Supplemental Files, UTr_cohort_ser_enz_vs_TE_dose.xlsx). This disparity may relate to the slightly different 
335

336

337

338

339

340

341

342

343

344

345

346

347

348

349

350

351

352

353

354

355

356

357

358

359

360

361

362

363

364

365

mean age of the two rat cohorts at the start of TE treatment, or a training-related change in resistance of the circulating enzymes' sources, or both.

Being fairly ubiquitous (Bataller-Sifré, Guiral-Olivan \& Bataller-Alberola, 2011), GGT alone has insufficient specificity as a serum marker of liver injury. In humans, it is usually raised in liver pathologies involving cholestasis and jaundice, including those caused by AAS (Urhausen, Torsten \& Wilfried, 2003; Lumia \& McGinnis, 2010). In rats, it is supposedly a better cholestasis marker than serum ALP but less reliable than in other species (Ozer et al., 2008). We found elevated serum ALP activity in only two out of 12 EndTr+TE80 rats, but only one of them showed moderately elevated serum GGT activity. Notably, testosterone or its esters rarely cause adverse hepatobiliary effects, except possibly in aging (Nucci et al., 2017).

Cell membrane-bound GGT is a vital part of hepatic antioxidant lines that sustain cellular GSH and cysteine homeostasis (Zhang, Forman \& Choi, 2005). Its link with serum GGT is not known. Serum GGT was proposed as an aggregate marker of organismal oxidative stress caused by various diseases and environmental chemicals (Lee \& Jacobs, 2009; Chang et al., 2013). The TE treatment-related differences in serum GGT and the occurrence of excessive serum GGT levels were much larger in the EndTr cohort than those found earlier (see Sadowska-Krępa et al., 2017) in the UTr cohort. However, there was no significant association between the levels of serum GGT and serum ALP, ALT, or AST. Hence, a significant part of the rise in serum GGT activity might not be due to liver stress or damage. Instead, it may indicate increased oxidative stress occurring in multiple organs.

Mean liver TBARS content was only slightly higher in the TE-untreated EndTr rats than in their UTr counterparts (Sadowska-Krępa et al., 2017); this could be related to the constitutively high liver metabolic activity and the corresponding oxidative stress. However, the relative differences in liver TBARS content between the EndTr+TE8 and EndTr+TE80 rats and their TEuntreated counterparts were modest $(+15$ and $+48 \%$, respectively) compared to those in their sedentary counterparts ( +56 and $+78 \%$, respectively, see Sadowska-Krępa et al., 2017). Hence, the absolute mean TBARS levels were nearly equal in the corresponding TE-treated UTr and EndTr rat groups. Though the present data confirm the pro-oxidant action of supraphysiological TE doses, they also suggest an attenuation of the added oxidative stress in the EndTr rats.

Decreased activities of liver CAT and SOD in high-dose TE-treated rats and negative correlations of these enzyme activities with weekly TE doses proved a harmful action of massive 
366

367

368

369

370

371

372

373

374

375

376

377

378

379

380

381

382

383

384

385

386

387

388

389

390

391

392

393

394

395

396

testosterone supplementation on liver antioxidant enzymes in adolescent EndTr rats. Even more significant relative declines, including those in GPx and GR activities, were found in the heart of EndTr male adolescent rats given testosterone propionate doses that produced much higher serum TT levels. Their associated relative increases in left heart ventricle TBARS content exceeded these in the liver. However, the maximum absolute mean TBARS contents found in the two organs were nearly identical to the respective maximum found in the soleus muscle and far above that in the extensor digitorum longus (Sadowska-Krepa et al., 2013). This similarity may be related to the fact that the soleus muscle, the myocardium, and the liver, but not the extensor digitorum longus, rely almost entirely on oxidative metabolism in exercise.

While we found decreased hepatic GSH content in our TE-treated EndTr rats, stanozolol treatment was reported to increase hepatic GSH content in endurance-trained rats (Pey et al., 2003). The cause of the difference may be distinct pharmacological profiles of stanozolol and testosterone (Fernandez et al., 1994; Hartgens \& Kuipers, 2004; Russmann, Kullak-Ublick \& Grattagliano, 2009; Büttner \& Thieme, 2010), but also younger age and thus different reactivity of our rats at the beginning of androgen treatment. The present data contrast also with those from adolescent UTr rats, in which the same TE doses significantly elevated liver SOD activity (Sadowska-Krępa et al., 2017). It is likely that long-term TE treatment of adolescent male EndTr rats perturbed their development and/or boosted oxidative stress beyond the capacity of hepatic defenses. Of note, mean liver activities of SOD, CAT and GPx were higher ( $p \leq 0.035$, onetailed $t$-test) in the TE-untreated EndTr rats than in their UTr counterparts (Sadowska-Krępa et al., 2017), and a similar tendency was found for GR ( $\mathrm{p}=0.093$, one-tailed $t$-test). These findings implied that the training alone boosted the antioxidant defenses. A similar effect on liver SOD but not CAT and GPx activities was found in male rats of similar age, which were given 16-week EndTr of similar intensity (Song, Igawa \& Horii, 1996). In our study, the positive effect of the training on liver SOD and CAT, but not GR and GPx activities, was dose-dependently reduced by concurrent TE treatment. This decline is consistent with enhanced liver oxidative stress adolescent UTr rats (Sadowska-Krępa et al., 2017) and prompt deactivation of CAT and SOD by oxygen free radicals (Salo et al., 1990; Escobar, Rubio \& Lassi, 1996).

GSH is the most abundant antioxidant and the key scavenger of reactive oxygen and nitrogen species in the liver (Russmann, Kullak-Ublick \& Grattagliano, 2009; Li et al., 2015). In our studies, its content did not differ between the TE-untreated EndTr and UTr rats. However, in 
397 contrast to what we found in the UTr rats study (Sadowska-Krępa et al., 2017), TE treatment 398 suppressed hepatic GSH content in EndTr rats, suggesting increased GSH use. GSH is also vital 399 for sustaining reduced forms of some exogenous antioxidants, including the essential lipophilic 400 antioxidant vitamin E (Scholz et al., 1989). Neither hepatic $\alpha$-tocopherol nor $\gamma$-tocopherol pool 401 was significantly affected by TE treatment in EndTr rats, showing the efficacy of GSH in 402 maintaining appropriate levels of these protectants against free-radical mediated liver damage 403 (Leo, Rosman \& Lieber, 1993). Interestingly, liver TBARS content negatively correlated with 404 hepatic $\alpha$-tocopherol $\left(\mathrm{R}_{\mathrm{S}}=-0.48, \mathrm{p}<0.01, \mathrm{~N}=31\right)$ but not $\gamma$-tocopherol content $\left(\mathrm{R}_{\mathrm{S}}=-0.30, \mathrm{p}=\right.$ $4050.11, \mathrm{~N}=31$ ) within the entire EndTr cohort. This link may reflect the use of $\alpha$-tocopherol for

406 407 408 409 410 411 412 413 414 415 416

\section{Conclusions}

418 The present results show that long-term systemic high-dose testosterone treatment harms liver 419 420 421 422 423 424 425 426 427 scavenging reactive oxygen species formed, e.g., due to $\beta$-oxidation of fatty acids, and hence for breaking chain propagation and maintaining an adequate redox balance (Niki, 2014).

The EndTr-related shifts in blood lipid profile found in this study are usually linked to reduced atherogenicity in both humans (Shephard \& Johnson, 2015; Ruegsegger \& Booth, 2018) and rats (Burneiko et al., 2006; Kazeminasab et al., 2017). The changes in blood lipid profile caused by concurrent TE treatment evidenced a reversal of the beneficial effects of the training and worsening of some training-unaffected characteristics except for the tendency of TG level and TG/HDL ratio to drop with the high TE dosage. The latter was likely the result of long-term action of supraphysiological serum TT level on male adipose tissue metabolism and the ensuing decreased body and liver fat contents and availability. antioxidant defense systems and function in adolescent male rats undergoing endurance training. Namely, it abolishes or markedly attenuates most studied metabolic benefits from the training, causing a negative shift in liver pro-oxidative/antioxidative balance evidenced by reduced SOD and CAT activities, raised hepatic TBARS level, and elevated serum GGT activity. These changes suggest increased oxidative stress that likely occurs in other organs as well and may increase morbidity later in life. The same may occur in human male adolescents using massive testosterone or other AAS supplementation as a shortcut to improved sports performance and/or a more muscular physical appearance. 


\section{References}

429

430

431

432

433

434

435

436

437

438

439

440

441

442

443

444

445

446

447

448

449

450

451

452

453

454

455

456

457

458

459

460

461

462

463

464

465

466

467

Aebi H. Catalase in vitro. Methods Enzymol 1984; 105: 121-125. DOI: 10.1016/s00766879(84)05016-3.

Arauz J, Ramos-Tovar E, Muriel P. Redox state and methods to evaluate oxidative stress in liver damage: from bench to bedside. Ann Hepatol 2016; 15: 160-173. DOI: $10.5604 / 16652681.1193701$.

Bataller-Sifre R, Guiral-Olivan V, Bataller-Alberola L. New clinical and toxicological scenario of gammaglutamyltranspeptidase. Rev Esp Enferm Dig 2011; 103: 586-590. DOI: 10.4321/s1130-01082011001100006.

Baume N, Schumacher YO, Sottas PE, Bagutti C, Cauderay M, Mangin P, Saugy M. Effect of multiple oral doses of androgenic anabolic steroids on endurance performance and serum indices of physical stress in healthy male subjects. Eur J Appl Physiol 2006; 98: 329-340. DOI: $10.1007 / \mathrm{s} 00421-006-0271-0$.

Belgorosky A, Rivarola MA. Changes in serum sex hormone-binding globulin and in serum nonsex hormone-binding globulin-bound testosterone during prepuberty in boys. J Steroid Biochem 1987a; 27: 291-295. DOI: 10.1016/0022-4731(87)90320-7.

Belgorosky A, Rivarola MA. Progressive increase in non-sex-hormone-binding globulin-bound testosterone from infancy to late prepuberty in boys. J Clin Endocrinol 1987b; 64: 482-485. DOI: $10.1210 /$ jcem-64-3-482.

Bond P, Llewellyn W, Van Mol P. Anabolic androgenic steroid-induced hepatotoxicity. Med Hypotheses 2016; 93: 150-153. DOI: 10.1016/j.mehy.2016.06.004.

Burneiko RC, Diniz YS, Galhardi CM, Rodrigues HG, Ebaid GM, Faine LA, Padovani CR, Cicogna AC, Novelli EL. Interaction of hypercaloric diet and physical exercise on lipid profile, oxidative stress and antioxidant defenses. Food Chem Toxicol 2006; 44: 1167-1172. DOI: $10.1016 /$ j.fct.2006.01.004.

Büttner A, Thieme D. Side effects of anabolic androgenic steroids: pathological findings and structure-activity relationships. Handb Exp Pharmacol 2010; 195: 459-484. DOI: 10.1007/978-3-540-79088-4_19.

Cerretani D, Neri M, Cantatore S, Ciallella C, Riezzo I, Turillazzi E, Fineschi V. Looking for organ damages due to anabolic-androgenic steroids (AAS): is oxidative stress the culprit? Mini-Rev Org Chem 2013; 10: 393-399. DOI: 10.2174/1570193X113106660025.

Chang Q, Miao X, Ju X, Zhu L, Huang C, Huang T, Zuo X, Gao C. Effects of pulse current on endurance exercise and its anti-fatigue properties in the hepatic tissue of trained rats. PLoS One 2013; 8: e75093. DOI: 10.1371/journal.pone.0075093.

Cichoż-Lach H, Michalak A. Oxidative stress as a crucial factor in liver diseases. World $J$ Gastroenterol 2014; 20: 8082-8091. DOI: 10.3748/wjg.v20.i25.8082.

Coffey VG, Hawley JA. Concurrent exercise training: do opposites distract? J Physiol 2017; 595: 2883-2896. DOI: 10.1113/JP272270.

De Pergola G. The adipose tissue metabolism: role of testosterone and dehydroepiandrosterone. Int J Obes Relat Metab Disord 2000; 24(Supp1 2): S59-S63. DOI: 10.1038/sj.ijo.0801280. 
468

477

478

479

480

481

482

483

484

485

486

487

488

489

490

491

492

493

494

495

496

497

498

499

500

501

502

503

504

505

506

507

Delgado J, Saborido A, Megias A. Prolonged treatment with the anabolic-androgenic steroid stanozolol increases antioxidant defences in rat skeletal muscle. J Physiol Biochem 2010; 66: 63-71. DOI: 10.1007/s13105-010-0010-1.

Dobrzyn P, Pyrkowska A, Duda MK, Bednarski T, Maczewski M, Langfort J, Dobrzyn A. Expression of lipogenic genes is upregulated in the heart with exercise training-induced but not pressure overload-induced left ventricular hypertrophy. Am J Physiol Endocrinol Metab 2013; 304: E1348-E1358. DOI: 10.1152/ajpendo.00603.2012.

Escobar JA, Rubio MA, Lassi EA. SOD and catalase inactivation by singlet oxygen and peroxyl radicals. Free Rad Biol Med 1996; 20: 285-290. DOI: 10.1016/0891-5849(95)02037-3.

Fernández L, Chirino R, Boada LD, Navarro D, Cabrera N, del Rio I, Díaz-Chico BN.

Stanozolol and danazol, unlike natural androgens, interact with the low affinity glucocorticoid-binding sites from male rat liver microsomes. Endocrinology 1994; 134: 14011408. DOI: 10.1210/endo.134.3.8119180.

Fikenzer K, Fikenzer S, Laufs U, Werner C. Effects of endurance training on serum lipids. Vascul Pharmacol 2018; 101: 9-20. DOI: 10.1016/j.vph.2017.11.005.

Foletto MP, Ferrari F, Peres SB, Moraes SMF, Segatelli TM, Mareze-da-Costa CE. Effects of anabolic steroid treatment associated with physical training in adipose tissue of male Wistar rats. Acta Scientiarum. Health Sciences 2015; 37: 19-24. DOI: 10.4025/actascihealthsci.v37i1.18614.

Frankenfeld SP, Oliveira LP, Ortenzi VH, Rego-Monteiro IC, Chaves EA, Ferreira AC, Leitão AC, Carvalho DP, Fortunato RS. The anabolic androgenic steroid nandrolone decanoate disrupts redox homeostasis in liver, heart and kidney of male Wistar rats. PLoS One 2014; 9: e102699. DOI: 10.1371/journal.pone.0102699.

Georgieva KN, Boyadjiev NP. Effects of nandrolone decanoate on $\mathrm{VO}_{2}$ max, running economy, and endurance in rats. Med Sci Sports Exerc 2004; 36: 1336-1341. DOI: 10.1249/01.mss.0000135781.42515.17.

Guengerich FP. Cytochrome P450 and chemical toxicology. Chem Res Toxicol 2008; 21: 70-83. DOI: $10.1021 / \mathrm{tx} 700079 \mathrm{z}$.

Handelsman DJ. Testosterone: use, misuse and abuse. Med J Aust 2006; 185: 436-439. DOI: 10.5694/j.1326-5377.2006.tb00642.x.

Harpur RP. The rat as a model for physical fitness studies. Comp Biochem Physiol 1980; 66A: 553-574. DOI: 10.1016/0300-9629(80)90001-8.

Hartgens F, Kuipers H. Effects of androgenic-anabolic steroids in athletes. Sports Med 2004; 34: 513-554. DOI: 10.2165/00007256-200434080-00003.

Horst HJ, Bartsch W, Dirksen-Thiedens I. Plasma testosterone, sex hormone binding globulin binding capacity and per cent binding of testosterone and $5 \alpha$-dihydrotestosterone in prepubertal, pubertal and adult males. J Clin Endocrinol Metab 1977; 45: 522-527. DOI: 10.1210/jcem-45-3-522.

Hoyos CM, Yee BJ, Phillips CL, Machan EA, Grunstein RR, Liu PY. Body compositional and cardiometabolic effects of testosterone therapy in obese men with severe obstructive sleep 
508

525

526

527

528

529

530

531

532

533

534

535

536

537

538

539

540

541

542

543

544

545

546

547

apnoea: a randomised placebo-controlled trial. Eur J Endocrinol 2012; 167: 531-541. DOI: 10.1530/EJE-12-0525.

Johnston LD, Miech RA, O’Malley PM, Bachman JG, Schulenberg JE, Patrick ME. (2019). Monitoring the Future national survey results on drug use: 1975-2018: Overview, key findings on adolescent drug use. Ann Arbor: Institute for Social Research, University of Michigan, MI, USA. Available online at: http://www.monitoringthefuture.org/pubs/monographs/mtfoverview2018.pdf. Accessed August 22, 2018.

Jones DP. Radical-free biology of oxidative stress. Am J Physiol Cell Physiol 2008; 295: C849C868. DOI: 10.1152/ajpcell.00283.2008.

Kanayama G, Pope HG Jr. History and epidemiology of anabolic androgens in athletes and nonathletes. Mol Cell Endocrinol 2018; 464: 4-13. DOI: 10.1016/j.mce.2017.02.039.

Kazeminasab F, Marandi M, Ghaedi K, Esfarjani F, Moshtaghian J. Effects of a 4-week aerobic exercise on lipid profile and expression of LXR $\alpha$ in rat liver. Cell J 2017; 19: 45-49. DOI: 10.22074/cellj.2016.4871.

Langfort J, Budohoski L, Newsholme EA. Effect of various types of acute exercise and exercise training on the insulin sensitivity of rat soleus muscle measured in vitro. Pflugers Arch 1988; 412: 101-105. DOI: 10.1007/bf00583737.

Langfort J, Czarnowski D, Pilis W, Wojcik B, Gorski J. Effect of various types of exercise training on 5'-nucleotidase and adenosine deaminase activities in rat heart: influence of a single bout of endurance exercise. Biochem Mol Med 1996; 59: 28-32. DOI: 10.1006/bmme.1996.0060.

Lee DH, Jacobs DR Jr. Serum $\gamma$-glutamyltransferase: new insights about an old enzyme. $J$ Epidemiol Community Health 2009; 63: 884-886. DOI: 10.1136/jech.2008.083592.

Leo MA, Rosman AS, Lieber CS. Differential depletion of carotenoids and tocopherol in liver disease. Hepatology 1993; 17: 977-986. DOI: 10.1002/hep.1840170606.

Li S, Tan HY, Wang N, Zhang ZJ, Lao L, Wong CW, Feng Y. The role of oxidative stress and antioxidants in liver diseases. Int J Mol Sci 2015; 16: 26087-26124. DOI: 10.3390/ijms161125942.

Lumia AR, McGinnis MY. Impact of anabolic androgenic steroids on adolescent males. Physiol Behav 2010; 100: 199-204. DOI: 10.1016/j.physbeh.2010.01.007.

Mantovani A, Fucic A. Puberty dysregulation and increased risk of disease in adult life: possible modes of action. Reprod Toxicol 2014; 44: 15-22. DOI: 10.1016/j.reprotox.2013.06.002.

Molano F, Saborido A, Delgado J, Morán M, Megías A. Rat liver lysosomal and mitochondrial activities are modified by anabolic-androgenic steroids. Med Sci Sports Exerc 1999; 31: 243250. DOI: 10.1097/00005768-199902000-00007.

Niki E. Role of vitamin E as a lipid-soluble peroxyl radical scavenger: in vitro and in vivo evidence. Free Radic Biol Med 2014; 66: 3-12. DOI: 10.1016/j.freeradbiomed.2013.03.022.

Nucci RAB, Teodoro ACS, Krause Neto W, Silva WA, de Souza RR, Anaruma CA, Gama EF. Effects of testosterone administration on liver structure and function in aging rats. Aging Male 2017; 20: 134-137. DOI: 10.1080/13685538.2017.1284779. 
548 Ohkawa H, Ohishi N, Yagi K. Assay for lipid peroxides in animal tissues by thiobarbituric acid

549

550

551

552

553

554

555

556

557

558

559

560

561

562

563

564

565

566

567

568

569

570

571

572

573

574

575

576

577

578

579

580

581

582

583

584

585

586

587 reaction. Anal Biochem 1979; 95: 351-358. DOI: 10.1016/0003-2697(79)90738-3.

Ozer J, Ratner M, Shaw M, Bailey W, Schomaker S. The current state of serum biomarkers of hepatotoxicity. Toxicology 2008; 245: 194-205. DOI: 10.1016/j.tox.2007.11.021.

Pettersson J, Hindorf U, Persson P, Bengtsson T, Malmqvist U, Werkström V, Ekelund M. Muscular exercise can cause highly pathological liver function tests in healthy men. $\mathrm{Br} J \mathrm{Clin}$ Pharmacol 2008; 65: 253-259. DOI: 10.1111/j.1365-2125.2007.03001.x.

Pey A, Saborido A, Blazquez I, Delgado J, Megias A. Effects of prolonged stanozolol treatment on antioxidant enzyme activities, oxidative stress markers, and heat shock protein HSP72 levels in rat liver. J Steroid Biochem Mol Biol 2003; 87: 269-277. DOI: 10.1016/j.jsbmb.2003.09.001.

Purdom T, Kravitz L, Dokladny K, Mermier C. Understanding the factors that effect maximal fat oxidation. J Int Soc Sports Nutr 2018; 15: 3. DOI: 10.1186/s12970-018-0207-1.

Romagnoli M, Alis R, Aloe R, Salvagno GL, Basterra J, Pareja-Galeano H, Sanchis-Gomar F, Lippi G. Influence of training and a maximal exercise test in analytical variability of muscular, hepatic, and cardiovascular biochemical variables. Scand J Clin Lab Invest 2014; 74: 192 198. DOI: $10.3109 / 00365513.2013 .873948$.

Ruegsegger GN, Booth FW. Health benefits of exercise. Cold Spring Harb Perspect Med 2018; 8: a029694. DOI: 10.1101/cshperspect.a029694.

Russmann S, Kullak-Ublick GA, Grattagliano I. Current concepts of mechanisms in druginduced hepatotoxicity. Curr Med Chem 2009; 16: 3041-3053. DOI: $10.2174 / 092986709788803097$.

Sadowska-Krepa E, Klapcinska B, Jagsz S, Chalimoniuk M, Chrapusta SJ, Wanke A, Grieb P, Langfort J. Diverging oxidative damage and heat shock protein 72 responses to endurance training and chronic testosterone propionate treatment in three striated muscle types of adolescent male rats. J Physiol Pharmacol 2013; 64: 639-647. PMID: 24304577.

Sadowska-Krępa E, Kłapcińska B, Jagsz S, Nowara A, Szołtysek-Bołdys I, Chalimoniuk M, Langfort J, Chrapusta SJ. High-dose testosterone enanthate supplementation boosts oxidative stress, but exerts little effect on the antioxidant barrier in sedentary adolescent male rat liver. Pharmacol Rep 2017; 69: 673-678. DOI: 10.1016/j.pharep.2017.02.023.

Salo DC, Pacifici RE, Lin SW, Giulivi C, Davies KJ. Superoxide dismutase undergoes proteolysis and fragmentation following oxidative modification and inactivation. $J$ Biol Chem 1990; 265: 11919-11927. PMID: 2195028.

Scholz RW, Graham KS, Gumpricht E, Reddy CC. Mechanism of interaction of vitamin E and glutathione in the protection against membrane lipid peroxidation. Ann NY Acad Sci 1989; 570: 514-517. DOI: 10.1111/j.1749-6632.1989.tb14973.x.

Shephard RJ, Johnson N. Effects of physical activity upon the liver. Eur J Appl Physiol 2015; 115: 1-46. DOI: 10.1007/s00421-014-3031-6.

Sies H. Oxidative stress: a concept in redox biology and medicine. Redox Biol 2015; 4: 180-183. DOI: $10.1016 /$ j.redox.2015.01.002. 
588 Singh A, Bhat TK, Sharma OP. Clinical biochemistry of hepatotoxicity. J Clin Toxicol 2011; S-

589

590

591

592

593

594

595

596

597

598

599

600

601

602

603

604

605

606

607

608

609

610

611

612

613

614

615

616

617

618

4: 001. DOI: 10.4172/2161-0495.S4-001.

Sobczak A, Skop B, Kula B. Simultaneous determination of serum retinol and $\alpha-$ and $\gamma$ tocopherol levels in type II diabetic patients using high-performance liquid chromatography with fluorescence detection. J Chromatogr B: Biomed Sci Appl 1999; 730: 265-271. DOI: 10.1016/s0378-4347(99)00141-3.

Solimini R, Rotolo MC, Mastrobattista L, Mortali C, Minutillo A, Pichini S, Pacifici R, Palmi I. Hepatotoxicity associated with illicit use of anabolic androgenic steroids in doping. Eur Rev Med Pharmacol Sci 2017; 21(1 Suppl): 7-16. PMID: 28379599.

Song Y, Igawa S, Horii A. Antioxidant enzymes response to endurance exercise training and dietary proteins in rat skeletal muscle and liver. Appl Hum Sci 1996; 15: 219-225. DOI: 10.2114/jpa.15.219.

Stárka L, Pospísilová H, Hill M. Free testosterone and free dihydrotestosterone throughout the life span of men. J Steroid Biochem Mol Biol 2009; 116: 118-120. DOI: 10.1016/j.jsbmb.2009.05.008.

Urhausen A, Torsten A, Wilfried K. Reversibility of the effects on blood cells, lipids, liver function and hormones in former anabolic-androgenic steroid abusers. $J$ Steroid Biochem Mol Biol 2003; 84: 369-375. DOI: 10.1016/S0960-0760(03)00105-5.

van Amsterdam J, Opperhuizen A, Hartgens F. Adverse health effects of anabolic-androgenic steroids. Regul Toxicol Pharmacol 2010; 57: 117-123. DOI: 10.1016/j.yrtph.2010.02.001.

Van Zyl CG, Noakes TD, Lambert MI. Anabolic-androgenic steroid increases running endurance in rats. Med Sci Sports Exerc 1995; 27: 1385-1389. PMID: 8531609.

Vanberg P, Atar D. Androgenic anabolic steroid abuse and the cardiovascular system. Handb Exp Pharmacol 2010; 195: 411-57. DOI: 10.1007/978-3-540-79088-4_18.

Vinken M, Maes M, Vanhaecke T, Rogiers V. Drug-induced liver injury: mechanisms, types and biomarkers. Curr Med Chem 2013; 20: 3011-13021. DOI: 10.2174/0929867311320240006.

Yu-Yahiro JA, Michael RH, Nasrallah DV, Schofield B. Morphologic and histologic abnormalities in female and male rats treated with anabolic steroids. Am J Sports Med 1989; 17: 686-689. DOI: 10.1177/036354658901700517.

Zhang H, Forman HJ, Choi J. $\gamma$-Glutamyl transpeptidase in glutathione biosynthesis. Methods Enzymol 2005; 401: 468-483. DOI: 10.1016/S0076-6879(05)01028-1.

Peer) reviewing PDF | (2020:03:46526:1:2:NEW 30 Sep 2020) 


\section{Table $\mathbf{1}$ (on next page)}

Comparison of body weight, liver weight and blood testosterone level between adolescent male rats given 6-week EndTr without or with concurrent weekly testosterone enanthate treatment.

BW, body weight; LW, liver weight; EndTr, endurance training; TE8, $8 \mathrm{mg} / \mathrm{kg} /$ week of intramuscular testosterone enanthate; TE $80,80 \mathrm{mg} / \mathrm{kg} /$ week of intramuscular testosterone enanthate; $\Pi$, total blood serum testosterone. Data are mean \pm standard deviation; rat numbers are shown in parentheses. $* p<0.05, * * p<0.01, * * * p<0.001$ vs. the respective EndTr group value; ${ }^{\# \#} p<0.01,{ }^{\# \# \#} p<0.001$ vs. the respective EndTr+TE8 group value; Tukey's test. 
1

\begin{tabular}{|c|c|c|c|c|}
\hline \multirow[b]{2}{*}{ Variable } & \multicolumn{3}{|c|}{ Rat group } & \multirow[b]{2}{*}{ ANOVA results } \\
\hline & EndTr & EndTr+TE8 & EndTr+TE80 & \\
\hline Initial BW [g] & $\begin{array}{r}102 \pm 5 \\
(10)\end{array}$ & $\begin{array}{l}111 \pm 7 \\
\quad(9)\end{array}$ & $\begin{array}{r}109 \pm 7 \\
(12)\end{array}$ & $\begin{array}{l}\text { TE dose: } \mathrm{F}_{2,28}=19.2, \mathrm{p}<10^{-3} \\
\text { Time: } \mathrm{F}_{1,28}=2165.4, \mathrm{p}<10^{-3}\end{array}$ \\
\hline Final BW [g] & $\begin{array}{l}301 \pm 27 \\
\quad(10)\end{array}$ & $\begin{array}{c}310 \pm 12 \\
(9)\end{array}$ & $\begin{array}{l}252 \pm 21^{* * *, \# \# \#} \\
\quad(12)\end{array}$ & $\begin{array}{l}\text { TE dose } \times \text { time interaction: } \\
\mathrm{F}_{2,28}=25.9, \mathrm{p}<10^{-3}\end{array}$ \\
\hline $\mathrm{LW}[\mathrm{g}]$ & $\begin{array}{c}10.30 \pm 1.41 \\
(10)\end{array}$ & $\begin{array}{c}12.40 \pm 1.59^{*} \\
(9)\end{array}$ & 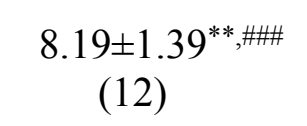 & $\mathrm{F}_{2,28}=21.7, \mathrm{p}<10^{-3}$ \\
\hline LW/BW [\%] & $\begin{array}{l}3.42 \pm 0.33 \\
\quad(10)\end{array}$ & $\begin{array}{l}3.99 \pm 0.45^{*} \\
(9)\end{array}$ & $\begin{array}{l}3.25 \pm 0.48^{\# \#} \\
(12)\end{array}$ & $\mathrm{F}_{2,28}=8.05, \mathrm{p}=0.0017$ \\
\hline $\mathrm{TT}[\mathrm{nmol} / \mathrm{l}]$ & $\begin{array}{c}3.24 \pm 2.07 \\
\quad(7)\end{array}$ & $\begin{array}{l}5.02 \pm 1.59 \\
(9)\end{array}$ & $\begin{array}{l}34.17 \pm 5.83^{* * *}, \# \# \# \\
(11)\end{array}$ & $\mathrm{F}_{2,24}=181.9, \mathrm{p}<10^{-3}$ \\
\hline
\end{tabular}

2 


\section{Table 2 (on next page)}

Liver levels of selected antioxidant enzymes, non-enzymatic antioxidants and TBARs in adolescent male rats given 6-week endurance training without or with concurrent testosterone enanthate treatment.

SOD, superoxide dismutase; CAT, catalase; GPx, glutathione peroxidase; GR, glutathione reductase; GSH, reduced glutathione; TBARs, thiobarbituric acid-reactive substances (lipid peroxidation products); EndTr, endurance training; TE8, $8 \mathrm{mg} / \mathrm{kg}_{\mathrm{Bw}} /$ week of intramuscular testosterone enanthate; TE80, $80 \mathrm{mg} / \mathrm{kg}_{\mathrm{Bw}} /$ week of intramuscular testosterone enanthate. ${ }^{\text {a }}$ per mg of protein in liver homogenate supernatant, ${ }^{b}$ per $g$ of liver wet weight; * $p<0.05, * *$ $p<0.01,{ }^{* * *} p<0.001$ vs. the respective EndTr group value; ${ }^{\ddagger} 0.05<p \leq 0.08$ vs. the respective EndTr+TE8 group value; Tukey's test. 
1

\begin{tabular}{|c|c|c|c|c|}
\hline \multirow[b]{2}{*}{$\begin{array}{l}\text { Antioxidant enzyme } \\
\text { activity, or low } \\
\text { molecular weight } \\
\text { antioxidant or } \\
\text { TBARS content }^{\mathrm{b}} \\
\end{array}$} & \multicolumn{3}{|c|}{ Rat group } & \multirow[b]{2}{*}{ ANOVA results } \\
\hline & $\begin{array}{l}\text { EndTr } \\
\mathrm{N}=10\end{array}$ & $\begin{array}{l}\text { EndTr+TE8 } \\
\quad \mathrm{N}=9\end{array}$ & $\begin{array}{l}\text { EndTr+TE80 } \\
\quad \mathrm{N}=12\end{array}$ & \\
\hline $\mathrm{SOD}[\mathrm{U} / \mathrm{mg} \text { protein }]^{\mathrm{a}}$ & $9.45 \pm 1.01$ & $8.82 \pm 0.45$ & $8.02 \pm 0.88^{* *}$ & $\mathrm{~F}_{2,28}=8.26, \mathrm{p}=0.002$ \\
\hline CAT [U/mg protein] ${ }^{\mathrm{a}}$ & $8.85 \pm 2.40$ & $4.00 \pm 1.35^{* * *}$ & $2.99 \pm 1.55^{* * *}$ & $\mathrm{~F}_{2,28}=30.9, \mathrm{p}<10^{-3}$ \\
\hline GPx [U/mg protein $]^{\mathrm{a}}$ & $310 \pm 66$ & $289 \pm 68$ & $281 \pm 65$ & $\mathrm{~F}_{2,28}=0.52, \mathrm{p}=0.60$ \\
\hline $\mathrm{GR}[\mathrm{mU} / \mathrm{mg} \text { protein }]^{\mathrm{a}}$ & $10.31 \pm 3.14$ & $9.22 \pm 4.21$ & $9.55 \pm 4.26$ & $\mathrm{~F}_{2,28}=0.20, \mathrm{p}=0.82$ \\
\hline $\mathrm{GSH}[\mu \mathrm{mol} / \mathrm{g} \text { tissue }]^{\mathrm{b}}$ & $4.24 \pm 1.20$ & $3.30 \pm 0.48^{*}$ & $3.77 \pm 0.50$ & $\mathrm{~F}_{2,28}=3.37, \mathrm{p}=0.049$ \\
\hline $\begin{array}{l}\alpha \text {-Tocopherol } \\
{[\mathrm{nmol} / \mathrm{g} \text { tissue }]^{\mathrm{b}}}\end{array}$ & $53.2 \pm 9.4$ & $55.8 \pm 5.3$ & $50.7 \pm 4.3$ & $\mathrm{~F}_{2,28}=1.54, \mathrm{p}=0.23$ \\
\hline $\begin{array}{l}\gamma \text {-Tocopherol } \\
{[\mathrm{nmol} / \mathrm{g} \text { tissue }]^{\mathrm{b}}}\end{array}$ & $0.99 \pm 0.19$ & $1.06 \pm 0.22$ & $0.96 \pm 0.19$ & $\mathrm{~F}_{2,28}=0.76, \mathrm{p}=0.48$ \\
\hline $\begin{array}{l}\text { TBARs } \\
{\text { [nmol MDA/g tissue }]^{\mathrm{b}}}\end{array}$ & $839 \pm 290$ & $962 \pm 56$ & $1245 \pm 325^{* *}$ & $\mathrm{~F}_{2,28}=6.91, \mathrm{p}=0.004$ \\
\hline
\end{tabular}




\section{Table 3 (on next page)}

Comparison of blood serum AST, ALT, ALP and GGT activities between adolescent male rats given 6 -week endurance training without or with concurrent testosterone enanthate treatment.

AST, aspartate aminotransferase; ALT, alanine aminotransferase; ALP, alkaline phosphatase; GGT, $\mathrm{y}$-glutamyltransferase. EndTr, endurance training; TE8, $8 \mathrm{mg} / \mathrm{kg}_{\mathrm{BW}} /$ week of intramuscular testosterone enanthate; TE80, $80 \mathrm{mg} / \mathrm{kg}_{\mathrm{Bw}} /$ week of intramuscular testosterone enanthate. ${ }^{*} p<0.05,{ }^{* * *} p<0.001$ vs. the respective EndTr group value; ${ }^{\ddagger} 0.05<p \leq 0.08$ vs. the respective EndTr+TE8 group value; Tukey's test. 
1

\begin{tabular}{lcccc}
\hline \multirow{2}{*}{$\begin{array}{l}\text { Blood serum } \\
\text { enzyme }\end{array}$} & $\begin{array}{c}\text { EndTr } \\
\mathrm{N}=10\end{array}$ & $\begin{array}{c}\text { EndTr+TE8 } \\
\mathrm{N}=9\end{array}$ & $\begin{array}{c}\text { EndTr+TE80 } \\
\mathrm{N}=12\end{array}$ & ANOVA results \\
\hline AST [U/1] & $179 \pm 47$ & $178 \pm 26$ & $189 \pm 23$ & $\mathrm{~F}_{2,28}=0.39, \mathrm{p}=0.68$ \\
ALT [U/1] & $61 \pm 14$ & $70 \pm 12$ & $75 \pm 15$ & $\mathrm{~F}_{2,28}=2.96, \mathrm{p}=0.068$ \\
ALP [U/1] & $157 \pm 30$ & $164 \pm 11$ & $180 \pm 14^{*}$ & $\mathrm{~F}_{2,28}=4.00, \mathrm{p}=0.030$ \\
GGT [U/1] & $1.14 \pm 0.25$ & $1.42 \pm 0.37$ & $1.79 \pm 0.33^{* * *}+$ & $\mathrm{F}_{2,28}=11.24, \mathrm{p}<10^{-3}$ \\
\hline
\end{tabular}

2 


\section{Table 4 (on next page)}

Occurrence of above-normal activities of blood serum AST, ALT, ALP and GGT in adolescent male rats given 6-week endurance training without or with concurrent testosterone enanthate treatment.

AST, aspartate aminotransferase; ALT, alanine aminotransferase; ALP, alkaline phosphatase; GGT, $\gamma$-glutamyltransferase. EndTr, endurance training; TE8, $8 \mathrm{mg} / \mathrm{kg}_{\mathrm{Bw}} /$ week of intramuscular testosterone enanthate; TE80, $80 \mathrm{mg} / \mathrm{kg}_{\mathrm{Bw}} /$ week of intramuscular testosterone enanthate. a Based on data from age-matched TE-untreated sedentary male Wistar rats (UTr, $\mathrm{N}=11)$ from the same breeding colony ( $\mathrm{Cmd}$ (WI)WU outbred stock) and kept under same conditions; taken from Sadowska-Krępa et al., 2017, with permission. ${ }^{10} 0.06 \leq p \leq 0.08,{ }^{\S}$ $p<0.05,{ }^{55} p<0.01,{ }^{555} p<0.001$ vs. the respective UTr group value $(0 / 11,0 \%$ for AST, ALT and ALP, and $0 / 10,0 \%$ for GGT); $* p<0.05,{ }^{* * *} p<0.001$ vs. the respective EndTr group value; ${ }^{\# *}$ $p<0.01$ vs. the respective EndTr+TE8 group value; the one-tailed $z$-test for two proportions. 
1

\begin{tabular}{|c|c|c|c|c|}
\hline \multirow{2}{*}{$\begin{array}{l}\text { Enzyme } \\
\text { activity }\end{array}$} & \multirow{2}{*}{$\begin{array}{l}\text { Surrogate } \\
\text { reference range }\end{array}$} & \multicolumn{3}{|c|}{ Occurrence of excessive enzyme activity } \\
\hline & & EndTr rats & EndTr+TE8 rats & EndTr+TE80 rats \\
\hline AST [U/1] & $124-163$ & $6 / 10(60 \%)^{\S \S}$ & $7 / 9(78 \%)^{\S \S \S}$ & $10 / 12(83 \%)^{\S \S \S}$ \\
\hline $\mathrm{ALT}[\mathrm{U} / 1]$ & $42-71$ & $2 / 10(20 \%)$ & $4 / 9(44 \%)^{\S \S}$ & $7 / 12(58 \%)^{\S \S, *}$ \\
\hline ALP [U/1] & $114-196$ & $1 / 10(10 \%)$ & $0 / 9(0 \%)$ & $2 / 12(17 \%)$ \\
\hline GGT [U/1] & $0.57-1.39$ & $2 / 10(20 \%)^{\oplus}$ & $3 / 9(33 \%)^{\S}$ & 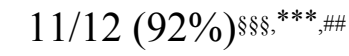 \\
\hline
\end{tabular}

2 


\section{Table 5 (on next page)}

Selected blood serum lipid levels and lipid ratios in adolescent male rats given 6-week EndTr without or with concurrent testosterone enanthate treatment and in their naive counterparts.

UTr, age-matched drug-naive untrained (sedentary) male Wistar rats from the same outbred stock (WI(WU)Cmd); EndTr, endurance training; TE8, $8 \mathrm{mg} / \mathrm{kg}_{\mathrm{Bw}} /$ week of intramuscular testosterone enanthate; TE80, $80 \mathrm{mg} / \mathrm{kg}_{\mathrm{Bw}} /$ week of intramuscular testosterone enanthate; Tot-Ch, total blood serum cholesterol; LDL-Ch, low-density lipoprotein cholesterol; HDL-Ch, high-density lipoprotein cholesterol; TG, triglycerides. " $0.06<p \leq 0.08, * p<0.05, * * * p<0.001$ vs. the respective EndTr group value, Dunnett's test. 
1

\begin{tabular}{lccccc}
\hline \multirow{2}{*}{$\begin{array}{l}\text { Blood serum lipid } \\
\text { or lipid ratio }\end{array}$} & \begin{tabular}{c}
$\mathrm{UTr}$ \\
\cline { 2 - 5 }
\end{tabular} & $\begin{array}{c}\text { EndTr } \\
\mathrm{N}=11\end{array}$ & $\begin{array}{c}\text { EndTr+TE8 } \\
\mathrm{N}=9\end{array}$ & $\begin{array}{c}\text { EndTr+TE80 } \\
\mathrm{N}=12\end{array}$ & ANOVA results \\
\hline Tot-Ch [mg/dl] & $87 \pm 10$ & $79 \pm 7$ & $75 \pm 10$ & $71 \pm 10$ & $\mathrm{~F}_{3,38}=6.19, \mathrm{p}=0.002$ \\
LDL-Ch [mg/dl] & $40 \pm 9$ & $33 \pm 7$ & $36 \pm 11$ & $36 \pm 8$ & $\mathrm{~F}_{3,38}=1.32, \mathrm{p}=0.28$ \\
HDL-Ch [mg/dl] & $30 \pm 3$ & $30 \pm 3$ & $24 \pm 4^{* * *}$ & $21 \pm 3^{* * *}$ & $\mathrm{~F}_{3,38}=23.4, \mathrm{p}<10^{-3}$ \\
Tot-Ch/HDL-Ch & $2.99 \pm 0.48$ & $2.62 \pm 0.32$ & $3.27 \pm 0.87^{\star}$ & $3.43 \pm 0.68^{*}$ & $\mathrm{~F}_{3,38}=3.56, \mathrm{p}=0.023$ \\
LDL-Ch/HDL-Ch & $1.39 \pm 0.39$ & $1.09 \pm 0.26$ & $1.62 \pm 0.70^{*}$ & $1.75 \pm 0.54^{*}$ & $\mathrm{~F}_{3,38}=3.55, \mathrm{p}=0.023$ \\
TG [mg/dl] & $71 \pm 16^{*}$ & $50 \pm 14$ & $61 \pm 18$ & $42 \pm 15$ & $\mathrm{~F}_{3,38}=7.31, \mathrm{p}<10^{-3}$ \\
TG/HDL-Ch & $2.42 \pm 0.61^{\uparrow}$ & $1.67 \pm 0.48$ & $2.72 \pm 1.14^{*}$ & $2.01 \pm 0.75$ & $\mathrm{~F}_{3,38}=3.56, \mathrm{p}=0.023$ \\
\hline
\end{tabular}

2 


\section{Table 6(on next page)}

Occurrence of abnormal blood serum Tot-Ch, LDL-Ch, HDL-Ch and TG levels in adolescent male rats given 6-week endurance training without or with concurrent testosterone enanthate treatment.

${ }^{\text {a }}$ Derived from the UTr group data shown in Table 5. ${ }^{\mathrm{b}} \mathrm{All}$ abnormal values were below the lower limit of the respective reference range; 'all abnormal values were above the upper limit of the respective reference range. EndTr, endurance training; TE8, $8 \mathrm{mg} / \mathrm{kg}_{\mathrm{Bw}} /$ week of intramuscular testosterone enanthate; TE80, $80 \mathrm{mg} / \mathrm{kg}_{\mathrm{Bw}} /$ week of intramuscular testosterone enanthate; Tot-Ch, total blood serum cholesterol; LDL-Ch, low-density lipoprotein cholesterol;

HDL-Ch, high-density lipoprotein cholesterol; TG, triglycerides. ${ }^{\S} p<0.05,{ }^{\S \S} p<0.01,{ }^{\$ \S} p<0.001$ vs. the respective $U \operatorname{Tr}$ group value $(0 / 11,0 \%) ;{ }^{\dagger} p=0.058, * p<0.05, * * p<0.01, * * * p<0.001$ vs. the respective EndTr group value; ${ }^{\# \#} p<0.01$ vs. the respective EndTr+TE8 group value, the one-tailed z-test for two proportions. 


\begin{tabular}{|c|c|c|c|c|}
\hline \multirow[t]{2}{*}{ Serum lipid index } & \multirow{2}{*}{$\begin{array}{c}\text { Surrogate } \\
\text { reference range }\end{array}$} & \multicolumn{3}{|c|}{ Occurrence of abnormal values } \\
\hline & & EndTr rats & EndTr+TE8 rats & EndTr+TE80 rats \\
\hline LDL-Ch [mg/dl] & $22-59$ & $0 / 10(0 \%)$ & $0 / 9(0 \%)$ & $0 / 12(0 \%)$ \\
\hline HDL-Ch $[\mathrm{mg} / \mathrm{dl}]^{\mathrm{b}}$ & $24-35$ & $0 / 10(0 \%)$ & $5 / 9(56 \%)^{\S \S,{ }^{* *}}$ & $9 / 12(75 \%)^{\S \S \S, * * *}$ \\
\hline Tot-Ch $[\mathrm{mg} / \mathrm{dl}]^{\mathrm{b}}$ & $68-107$ & $0 / 10(0 \%)$ & $1 / 9(11 \%)$ & $4 / 12(33 \%)^{\S,}{ }^{*}$ \\
\hline Tot-Ch/HDL-Ch ${ }^{\mathrm{c}}$ & $2.03-3.95$ & $0 / 10(0 \%)$ & $2 / 9(22 \%)^{\S, \dagger}$ & $3 / 12(25 \%)^{\S,}{ }^{*}$ \\
\hline LDL-Ch/HDL-Ch ${ }^{\mathrm{c}}$ & $0.61-2.17$ & $0 / 10(0 \%)$ & $2 / 9(22 \%)^{\S, \dagger}$ & $3 / 12(25 \%)^{\S, *}$ \\
\hline $\mathrm{TG}[\mathrm{mg} / \mathrm{dl}]^{\mathrm{b}}$ & $39-103$ & $1 / 10(10 \%)$ & $0 / 9(0 \%)$ & $7 / 12(58 \%)^{\S \S, * * \# \#}$ \\
\hline TG/HDL-Ch & $1.21-3.64$ & $1 / 10(10 \%)$ & $2 / 9(22 \%)^{\S}$ & $1 / 12(8 \%)$ \\
\hline
\end{tabular}

